\title{
Regenerated Hair Cells Can Originate from Supporting Cell Progeny: Evidence from Phototoxicity and Laser Ablation Experiments in the Lateral Line System
}

\author{
Kenneth J. Balak, ${ }^{1,2}$ Jeffrey T. Corwin, ${ }^{1}$ and Jay E. Jones ${ }^{1}$ \\ 'Departments of Otolaryngology and Neuroscience, University of Virginia School of Medicine, Charlottesville, Virginia \\ 22908, and 'Department of Biology, Western Kentucky University, Bowling Green, Kentucky 42101
}

The mechanisms that lead to the production of sensory hair cells during regeneration have been investigated by using 2 different procedures to ablate preexisting hair cells in individual neuromast sensory epithelia of the lateral line in the tails of salamanders, then monitoring the responses of surviving cells.

In one series of experiments, fluorescent excitation was used to cause the phototoxic death of hair cells that selectively take up the pyridinium dye DASPEI. In the other experiments, the ultraviolet output of a pulsed neodymiumYAG laser was focused to a microbeam through a quartz objective lens in epi-illumination mode and used to selectively kill individual unlabeled hair cells while the cells were simultaneously imaged by transmitted light DIC microscopy.

Through observation of the treated neuromasts in vivo, these experiments demonstrated that mature sensory epithelia that have been completely depleted of hair cells can still generate new hair cells. Preexisting hair cells are not necessary for regeneration. Immediately after the ablations the only resident cells in the sensory epithelia were supporting cells. These cells were observed to divide at rates that were increased over control values, and eventually those cell divisions gave rise to progeny that differentiated as hair cells, replacing those that had been killed. Macrophages were active in these epithelia, and their phagocytic activity had a significant influence on the standing population of cells. The first new hair cells appeared 3-5 d after the treatments, and additional hair cells usually appeared every 1$2 \mathrm{~d}$ for at least 2 weeks. We conclude that the fate of the progeny produced by supporting cell divisions is plastic to a degree, in that these progeny can differentiate either as supporting cells or as hair cells in epithelia where hair cells are missing or depleted.

Received Dec. 7, 1989; revised Mar. 26, 1990; accepted Mar. 30, 1990.
This work was supported by a grant and an RCDA from NIII to J.T.C.; by a
grant from the Deafness Research Foundation to K.J.B., and by NIH Grant
RR01192 funding the LAMP Biotechnology Resource under the direction of Dr.
Michael W. Berns. We wish to thank Christine Laverack, Paula Borden Reed,
and Dr. Piera Sun for excellent technical assistance and Arlene Trader for generous
assistance. We are grateful to Dr. Berns and the staffof the Beckman Laser Institute
for the use of their facilities and for their help and guidance in laser cell surgery.
We thank Dr. Mark Warchol for suggestions that improved the manuscript.
Correspondence should be addressed to Dr. Jeffrey T. Corwin, Departments of
Otolaryngology and Neuroscience, Box 396. University of Virginia School of
Medicine, Charlottesville, VA 22908 .
Copyright @ 1990 Society for Neuroscience 0270-6474/90/082502-11\$03.00/0
Sensorineural hearing loss, commonly known as "nerve deafness," affects more than $80 \%$ of patients who have a significant loss of auditory sensitivity, over 17 million individuals in the United States alone. The primary cause of this disorder is loss of the sensory hair cells that are the initial transducers which change sound energy into transmembrane electrical activity in the cochlea. Causes of hair cell death include exposure to loud sound, poisoning by aminoglycoside antibiotics and by chemotherapy agents, infections, hereditary disorders, and unidentified events associated with aging (Bredberg, 1968; Nielson and Slepecky, 1986; Rybak, 1986; Yoo, 1986). Deafness that results from loss of hair cells has been assumed to be permanent in humans, because the production of these cells normally ends prior to birth in mammals and birds, as shown by DNA labeling and cell counting (Ruben, 1967; Tilney and Tilney, 1986; Katayama and Corwin, 1989). However, it has recently been discovered that regenerative production of sensory hair cells can occur in birds after a loss of hair cells caused by acoustic overstimulation, and this regeneration produces a healed epithelium in $10 \mathrm{~d}$ (Corwin and Cotanche, 1988; Ryals and Rubel, 1988). Electrophysiological measurements indicate that regeneration of hair cells results in recovery of auditory function (Saunders and Tilney, 1982; Tucci and Rubel, 1989).

The cell populations in the auditory epithelia in birds are mitotically quiescent during normal postembryonic life, like their counterparts in mammals. However, when hair cells have been killed, the avian sensory epithelium responds by reactive cell division. If tritiated thymidine is available in the bloodstream following acoustic trauma that has killed hair cells, it becomes incorporated in newly replicated DNA in both the hair cells and the supporting cells at the site of the healed lesion. The question has remained whether both types of cells divide during regeneration. In the experiments cited (Corwin and Cotanche, 1988; Ryals and Rubel, 1988), the thymidine tracer was available for $7-10 \mathrm{~d}$, so the labeling could either have resulted from divisions in both cell types or from early divisions in one cell type that gave rise to progeny that eventually differentiated to produce 2 types of cells.

Measured correspondences between the local frequencies of labeling in the hair cells and supporting cells are consistent with the proposal that the 2 types of cells originate from a common progenitor (Corwin and Cotanche, 1988). Other evidence suggests that existing supporting cells may be the common progenitors. Supporting cells proliferate in continuously growing hair cell epithelia in the ears of fish and amphibians, and in some species the populations appear to turn over (Corwin, 1977, 
1981, 1984, 1985; Jørgensen, 1981; Jørgensen and Mathiesen, 1988). Close spatial and temporal correspondences between the ccll divisions that give rise to hair cells and those that give rise to supporting cells are characteristic of cytogenesis in the embryonic avian cochlea, which has led to the proposal that the cells may share a single bipotent progenitor in the terminal mitosis before differentiation (Katayama and Corwin, 1989).

At sites where hair cells have been killed, supporting cells often survive, so their suspected role as a progenitor of replacement hair cells has added significance. It may be that the capacity for self-repair could be extended to mammals where surviving supporting cells apparently to not divide spontaneously after trauma, but might be induced to divide if they were treated appropriately. For that reason, we have specifically evaluated the potential progenitor function of supporting cells that survive at the sites of hair cell lesions.

Microscopic observations of living hair cell epithelia in the mechanoreceptive lateral line system in aquatic salamanders have provided support for the proposal that supporting cell divisions may be a source of progeny that can differentiate as either supporting cells or as replacement hair cells (Corwin, 1986; Balak and Corwin, 1988; Jones and Corwin, 1988; Corwin et al., 1989). In this study, 2 protocols were used to achieve ablations of hair cell populations in identified neuromasts, the small, isolated sensory epithelia of the lateral line system in the tails of young axolotl salamanders. In one series of experiments, salamanders were immersed in a vital fluorescent dye that is selectively taken up by hair cells. Then one sensory epithelium on the tail was exposed to UV excitation, so that the hair cells were selectively killed by a phototoxic chemical reaction. In the other series of experiments, all of the hair cells in an epithelium were individually killed by single pulses of intense UV light from a laser that was brought to focus in the nuclei of the cells. The responses of the supporting cells that survived these treatments were monitored by light microscopic observations of the cells in living preparations and by histological processing at stages during the course of subsequent hair cell regeneration.

\section{Materials and Methods}

Embryonic axolotl salamanders, Ambystoma mexicanum, of the "white" and "albino" strains were obtained from the Indiana University Axolotl Colony and raised in 20\% Holtfreter's solution until hatching. After hatching they were transferred to $50 \%$ Holtfreter's solution and were fed live brine shrimp larvae. Two to four weeks after hatching, the axolotls had grown to $20-30 \mathrm{~mm}$ total length. The axolotls used in these experiments were generally in those ranges of size and age. During surgery and microscopic observations, the axolotls were anesthetized by immersion in $100 \%$ Holtfreter's solution containing $0.007 \%$ benzocaine (ethyl-p-aminobenzoate).

Phototoxic ablations. Hair cells in the surface neuromast organs of the lateral line systems in fish and amphibians are specifically labeled when the intact animal is immersed in a solution of the vital fluorescent dye DASPEI [2-(4-dimethylaminostyryl)- $N$-ethyl pyridinium iodide] (Bereiter-Hahn, 1976; Jørgensen, 1989). The specific uptake of DASPEI permitted selective ablation of hair cells through extended exposure of labeled cells to light that excitcd the chromophorc, thercby producing phototoxic conditions in the hair cells. Hair cells of the lateral line sensory epithelia were labeled by immersing an axolotl in $1 \mathrm{~mm}$ DASPEI (Molecular Probes, Eugene, OR) in the benzocaine-Holtfreter's solution for $20 \mathrm{~min}$. The axolotl was then rinsed in benzocaine-Holtfreter's solution and transferred to a viewing chamber where it was held by magnetic restraints.

For ablation of hair cells, the open viewing chamber containing the DASPEI-labeled axolotl was placed on a Leitz Dialux microscope equipped with a silicon intensified target (SIT) video camera attached to the trinocular tube, with Zeiss differential interference contrast (DIC) optics, and with a $50 \mathrm{~W}$ HBO epifluorescent illumination system. The chamber was positioned so that a single identifiable hair cell epithelium was brought into focus by a $40 \times(0.75$ N.A.) water-immersion objective lens. A videotape record of the epithelium was made with DIC optics and with epifluorescent illumination prior to ablation. Then the epithelium was exposed to epifluorescent illumination at $450-490 \mathrm{~nm}$ wavelengths (Leitz, I-2 filter block) for $1 \mathrm{hr}$ or until the fluorescence had been significantly bleached from the hair cells. After irradiation the axolotl was transferred to $100 \%$ Holtfreter's solution in its normal container, where it recovered from anesthesia in minutes. The effect of the irradiation was monitored the next day by again immersing the axolotl in $1 \mathrm{~mm}$ DASPEI in benzocaine-Holtfreter's solution for $20 \mathrm{~min}$, then rinsing it, and examining the irradiated sensory epithelium with DIC optics and with epifuorescent illumination. In this way we checked for the presence of surviving hair cells in the treated neuromast. Hair cells were recognizable by DIC microscopy because of the presence of large spherical nuclei, apical bundles of stereocilia, and their central location in the neuromast. Staining with DASPEI identified hair cells in fluorescence microscopy. If any hair cells were observed, the procedure for phototoxic ablation was repeated. When no hair cells could be detected by either method of observation, the DIC and the epifluorescence images of the neuromast were recorded on videotape. The treated hair cell epithelia were examined for the presence of regenerated hair cells at 3$4 \mathrm{~d}$ intervals by relabeling with DASPEI and observing with both DIC and epifluorescence optics. Videotape records were made throughout the recovery period.

Laser ablations. Laser ablation experiments were conducted at the Beckman Laser Institute and Medical Clinic, University of California at Irvine. The third harmonic, UV $(355 \mathrm{~nm})$ output from a $1.5 \mathrm{~J}$ pulsed neodymium-YAG (yttrium-aluminum-garnet) laser was used to selectively kill individual hair cells in the sensory epithelia of the lateral line. For laser ablations, an axolotl was anesthetized in benzocaineHoltfreter's solution and placed in an open viewing chamber made from a coverglass and magnetic tape. The axolotl was restrained by pins held by magnetic attachments, and its tail was viewed through the coverglass bottom using an inverted Zeiss Axiomat microscope equipped with a newvicon video camera. $\Lambda$ n identifiable neuromast was brought into focus with a $100 \times(1.25$ N.A.) quartz objective lens (Fig. 1). Transmitted light and DIC optics were used for observation of the specimen throughout the experiments. The laser beam was directed to the specimen through the epi-illumination path of the microscope, so that the transmitted light observation was uninterrupted. The laser output ranged from 8 to $45 \mathrm{~mJ} /$ pulse at $355 \mathrm{~nm}$. Beam energy was monitored before and after ablations in a neuromast. The intensity of the pulses was attenuated $2-30 \mathrm{~dB}$ (referenced to the transmission through parallel polarizers) by adjusting crossed polarizers placed between the laser and the mirrors that directed the beam into the epi-illumination path of the microscope. Single pulses of the laser focused to a $1 \mu \mathrm{m}$ microbeam through the objective lens were sufficient to kill a cell when the plane of focus was at the nucleus. In some cases, more than one pulse was given to ensurc cell death. A laser pulse produced either a coagulation, appearing as a darkened circle of $1-2 \mu \mathrm{m}$ diameter, or the rapid formation and collapse of a small ionized plasma bubble at the level of focus in the nucleus. When either occurred, the preparation was repositioned so that another hair cell nucleus was brought beneath cross hairs that marked the location of the microbeam focus, and that cell was treated. This procedure was repeated until every hair cell in the neuromast had been treated.

The death of the hair cells was quickly evident. A change in the DIC appearance of the nucleus occurred seconds after the laser microbeam pulse to the cell. Then, within 15 min, each laser-treated cell was extruded from the neuromast, as described under Results. The laser treatments, and in many cases the extrusions of the hair cells, were recorded on videotape.

The responses of the lascr-trcatcd ncuromasts were monitored by several methods. The extrusion response, which has previously been reported from conditions when hair cells have been subjected to physiological compromise (Corwin, 1985, 1986; Cotanche et al., 1987), was monitored by 2 methods. In one case, a $1 \mathrm{~min}$ immersion in $1 \mathrm{~mm}$ DASPEI in benzocaine-Holtfreter's solution was used to label the hair cells of the epithelium prior to laser treatment. This permitted specific epifluorescent visualization of the living hair cells before laser treatment, and visualization of the remains of the same hair cells less than $15 \mathrm{~min}$ after laser ablation. Other axolotls were overanesthetized and then fixed $10 \mathrm{~min}-2 \mathrm{hr}$ after laser treatment in a solution containing $3 \%$ glutar- 


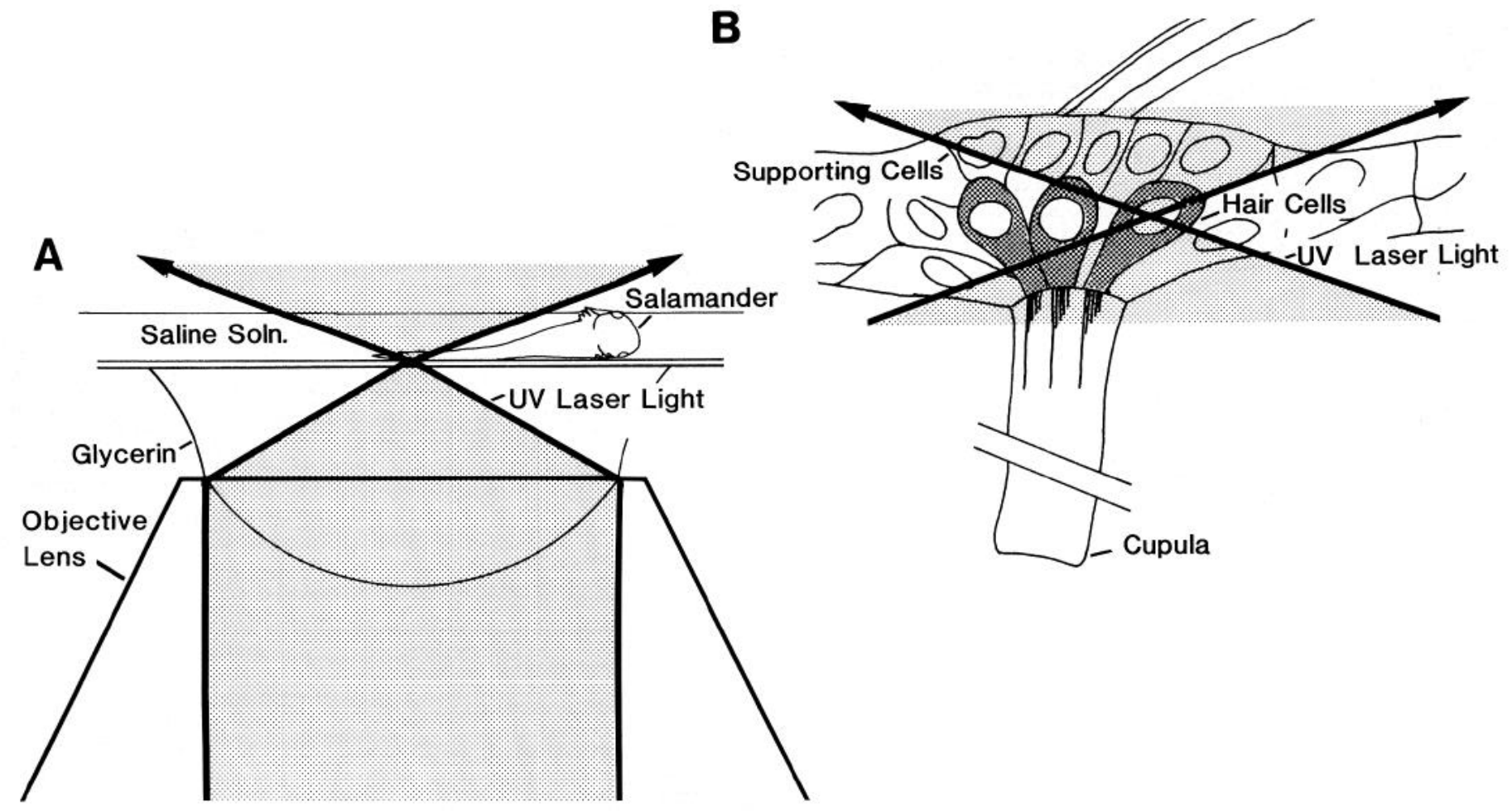

Figure 1. Schematic illustration of hair cell ablation using the laser microbeam. A, The tip of the quartz objective lens, linked to the observation chamber by immersion glycerin, and the anesthetized juvenile salamander are shown. Stippling illustrates the path of the laser light which is led to the back aperture of the 1.25 N.A. objective through the epi-illumination channel of the microscope and converges on the specimen with the cone angle illustrated. $B$, The focal point of the laser microbeam as it converges, at the actual cone angle employed, in the nucleus of a hair cell in a lateral line neuromast in the skin on the undersurface of the salamander. The exit angle illustrated in $A$ and the magnified representation of both the entrance and exit angles in $B$ are drawn with a correction for the refractive index difference between glycerol and saline solution. In the treatments used, the intensity of the $3 \mathrm{nsec}$ pulse of the laser was adjusted so that its destructive effect was limited to the site of focus, where the $355 \mathrm{~nm}$ photons were brought to convergence. At levels above and below the focal point the cross-sectional area of the beam was so much larger that the energy intensity, per unit area, was appreciably lower. In the overwhelming majority of treatments we detected no damage in either the overlying epidermal cells or the underlying supporting cells.

aldehyde in $0.1 \mathrm{~m}$ cacodylate buffer at $\mathrm{pH}$ 7.4. Then their tails were prepared for examination by scanning electron microscopy or for embedding and sectioning according to standard methods (Corwin, 1981).

Two specimens were laser-irradiated in the open observation chamber, then quickly transferred to a sealed observation chamber (Jones and Corwin, 1988) that permitted continuous time-lapse observation on an inverted microscope. The salamander was held by magnetic restraints inside the chamber and a sterile solution of $0.007 \%$ benzocaine in Holtfreter's solution was passed through the chamber at $40 \mathrm{ml} / \mathrm{hr}$. At roughly $48 \mathrm{hr}$ intervals, the chamber was removed from the microscope, the salamander was released into nonanesthetic Holtfreter's solution, where it was fed live brine shrimp larvae, and the chamber was cleaned. The salamander was then reanesthetized and positioned for continuation of the time-lapse microscopy, usually within $3 \mathrm{hr}$ of its release. The time-lapse record was made using a Zeiss IM inverted microscope equipped with a $40 \times(0.65$ N.A. $)$ objective lens, DIC optics, and a Hamamatsu newvicon video camera linked to a Gyyr time-lapse video casette recorder. The time-lapse factor was 120 to 1 .

\section{Results}

\section{Phototoxicity experiments}

The neuromast sensory epithelia of the mechanoreceptive lateral line in axolotl salamanders consist of up to 30 hair cells located superficial to a deep layer of supporting cell nuclei. The supporting cells in the lateral line epithelia are divisible into 2 subclasses. Internal supporting cells are located in the center of the neuromast. Their wide bases form a complete sheet over the basal lamina, and their narrower apical processes surround and separate adjacent hair cells. Mantle-type supporting cells are located peripheral to the internal supporting cells and the hair cells, where they form a rind of cells that delimits the boundary between the neuromast and the surrounding and overlying epidermis. The hair cell bodies are pear-shaped, with narrow apical regions and wide bases that extend only part of the distance to the base of the epithelium (Fig. 1B). A single thin layer of epidermal cells covers the surface of the neuromast except at the narrow sensory pore where the sensory hair bundles of the hair cells, the thin surfaces of supporting cells, and an acellular, gelatinous cupula project into the surrounding water (Fig. 2). The transparency of the thin tail in the pigmentationdeficient strains of axolotl salamanders that were used permitted direct high-magnification observations of the living cells in these epithelia viewed in vivo by DIC microscopy using transmitted light.

Immersion of an axolotl in a solution of DASPEI labeled only the hair cells of the lateral line sensory epithelia (Fig. 3, $A, B$ ). No other cells in the neuromast or in surrounding or underlying tissues of the tail (e.g., muscle, nerve, or notochord) took up the fluorescent dye. Immersion in $1 \mathrm{~mm}$ DASPEI with $0.007 \%$ benzocaine anesthetic in Holtfreter's saline solution was sufficient to produce bright fluorescent labeling of hair cells in $1 \mathrm{~min}$; however, $20 \mathrm{~min}$ immersions were used for the phototoxicity experiments, so as to saturate the cells. In contrast, only extremely weak labeling of hair cells resulted even after $30 \mathrm{~min}$ immersions when the $1 \mathrm{~mm}$ DASPEI and Holtfreter's solution 


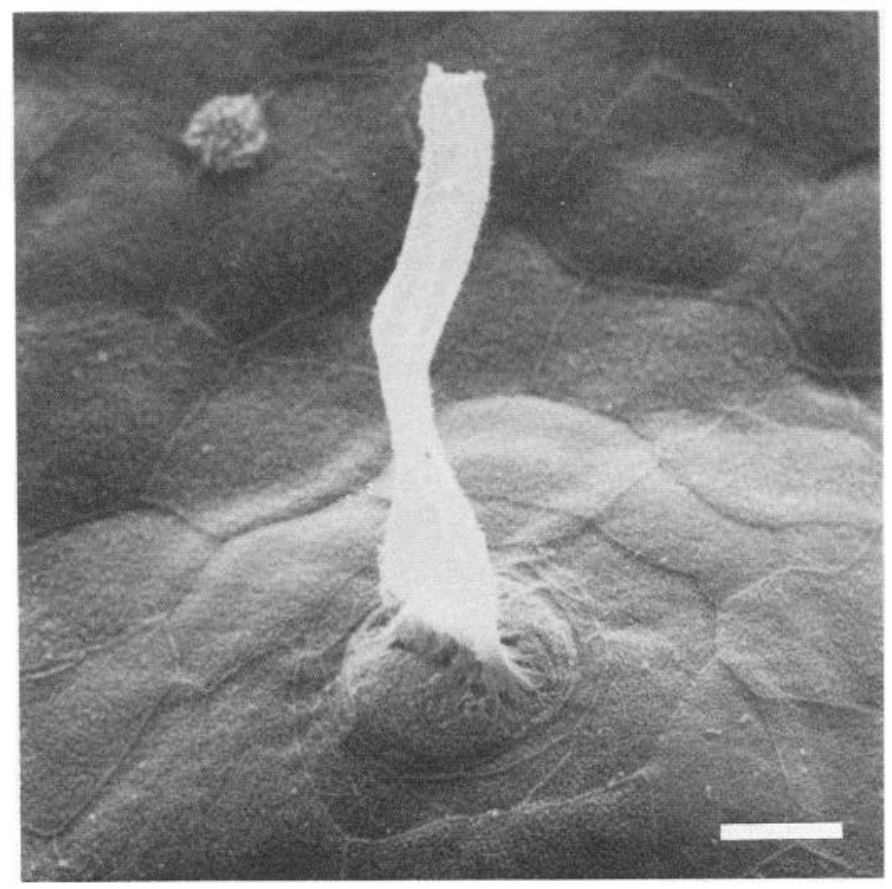

Figure 2. Scanning electron micrograph of an intact lateral line neuromast at the surface of the tail of a salamander. The sensory hair bundles at the apical surfaces of the hair cells are embedded in the base of the acellular, gelatinous cupula, which appears as the white vanelike structure running vertically in the micrograph. The cupula projects from the circular sensory pore at the apex of the neuromast into the water outside the skin. Drag along the cupula's long axis that parallels the skin surface stimulates the underlying rows of hair cells by causing bending of their hair bundles. Scale bar, $10 \mu \mathrm{m}$.

contained $0.007 \%$ MS-222 (ethyl- $m$-aminobenzoate) as the anesthetic, instead of $0.007 \%$ benzocaine (ethyl- $p$-aminobenzoate).

Excitation of the DASPEI chromophore by UV light was used to kill the heavily labeled hair cells by phototoxicity. After a 1 hr exposure to UV epi-illumination, these cells were damaged beyond healing. Over the next $24 \mathrm{hr}$, the treated hair cells were eliminated from the neuromast, presumably through extrusion from the apical sensory pore. Usually, the epithelia contained no hair cells when examined $1 \mathrm{~d}$ after treatment. The results of a DASPEI phototoxicity experiment are illustrated in Figure 3. The neuromast, which contains at least 20 hair cells, is shown in Figure 3, $A, B$, as a DIC photomicrograph and an epifluorescent video micrograph that were taken before the extended UV irradiation of the DASPEI chromophore. The same neuromast is shown in Figure $3, C, D$, taken $1 \mathrm{~d}$ later, $24 \mathrm{hr}$ after the phototoxic treatment. At that time, the neuromast consisted of a single, thin layer of covering epidermal cells and a flattened layer of supporting cells, with no hair cells to take up the fluorescent DASPEI label. Figure $3, E, F$, shows the same neuromast $9 \mathrm{~d}$ later, after 9 new hair cells had regenerated.

As a test to control for toxic effects of UV light exposure that might not have been related to fluorescent phototoxicity, neuromasts that contained 8-25 hair cells were treated with the same UV light exposure used in phototoxic ablation experiments, but without prior immersion in the hair cell labeling DASPEI solution. Examination of those epithelia $24 \mathrm{hr}$ later showed that none of the hair cells had been killed (Table 1).

Different durations of immersion in the DASPEI solution and

\begin{tabular}{|c|c|c|c|}
\hline \multirow{2}{*}{$\begin{array}{l}\text { Duration of } \\
\text { immersion } \\
(\mathrm{min})\end{array}$} & \multicolumn{2}{|c|}{ Number of hair cells } & \multirow{2}{*}{$\begin{array}{l}\text { Percent } \\
\text { killed }\end{array}$} \\
\hline & Before & After & \\
\hline 0 & 17 & 17 & 0 \\
\hline 0 & 25 & 25 & 0 \\
\hline 0 & 8 & 8 & 0 \\
\hline 5 & 17 & 1 & 94 \\
\hline 5 & 14 & 1 & 93 \\
\hline 10 & 17 & 0 & 100 \\
\hline 10 & 9 & 1 & 89 \\
\hline 20 & 13 & 0 & 100 \\
\hline 20 & 9 & 0 & 100 \\
\hline 30 & 12 & 0 & 100 \\
\hline 30 & 18 & 0 & 100 \\
\hline
\end{tabular}

Hair cells were visualized by DIC miscroscopy as described in Materials and Methods. Counts were made just prior to the treatments and $24 \mathrm{hr}$ after treatments.

different durations of epifluorescent excitation of the chromophore were used to measure their effectiveness in hair cell ablation. Immersions for less than 20 min resulted in ablation of most hair cells, but some remained viable a day after the treatment (Table 1). Immersions longer than $30 \mathrm{~min}$ resulted in the death of the salamander.

Holding the duration of immersion in the DASPEI solution constant at $20 \mathrm{~min}$ and increasing the duration of epi-illumination from 5 to 20 min caused increased ablation of hair cells (Table 2). However, even exposures as short as $5 \mathrm{~min}$ resulted in the elimination of the majority of the hair cells in a neuromast. Complete ablations were routinely achieved by using $1 \mathrm{hr}$ of epi-illumination. The concentration of DASPEI in the solution was not varied.

Phototoxic ablation after DASPEI treatment specifically eliminated hair cells, without producing a noticeable change in the neighboring population of supporting cells. Counts of supporting cells before and after complete ablation of all the hair cells in 3 neuromasts showed that the numbers of supporting cells were

Table 2. Changes in phototoxicity with different durations of UV irradiation following $20 \mathrm{~min}$ immersions in $1 \mathrm{~mm}$ DASPEI

\begin{tabular}{lccc}
$\begin{array}{l}\text { Duration } \\
\text { of UV } \\
\text { irradiation } \\
\text { (min) }\end{array}$ & \multicolumn{2}{l}{ Number of hair cells } & \\
\cline { 2 - 3 } & Before & After & $\begin{array}{l}\text { Percent } \\
\text { killed }\end{array}$ \\
\hline 0 & 3 & 3 & 0 \\
0 & 5 & 5 & 0 \\
0 & 13 & 13 & 0 \\
5 & 14 & 2 & 86 \\
5 & 3 & 1 & 67 \\
10 & 6 & 2 & 67 \\
10 & 6 & 1 & 83 \\
20 & 19 & 0 & 100 \\
20 & 19 & 0 & 100 \\
30 & 9 & 0 & 100 \\
30 & 15 & 0 & 100 \\
\hline
\end{tabular}

See note to Table 1 . 

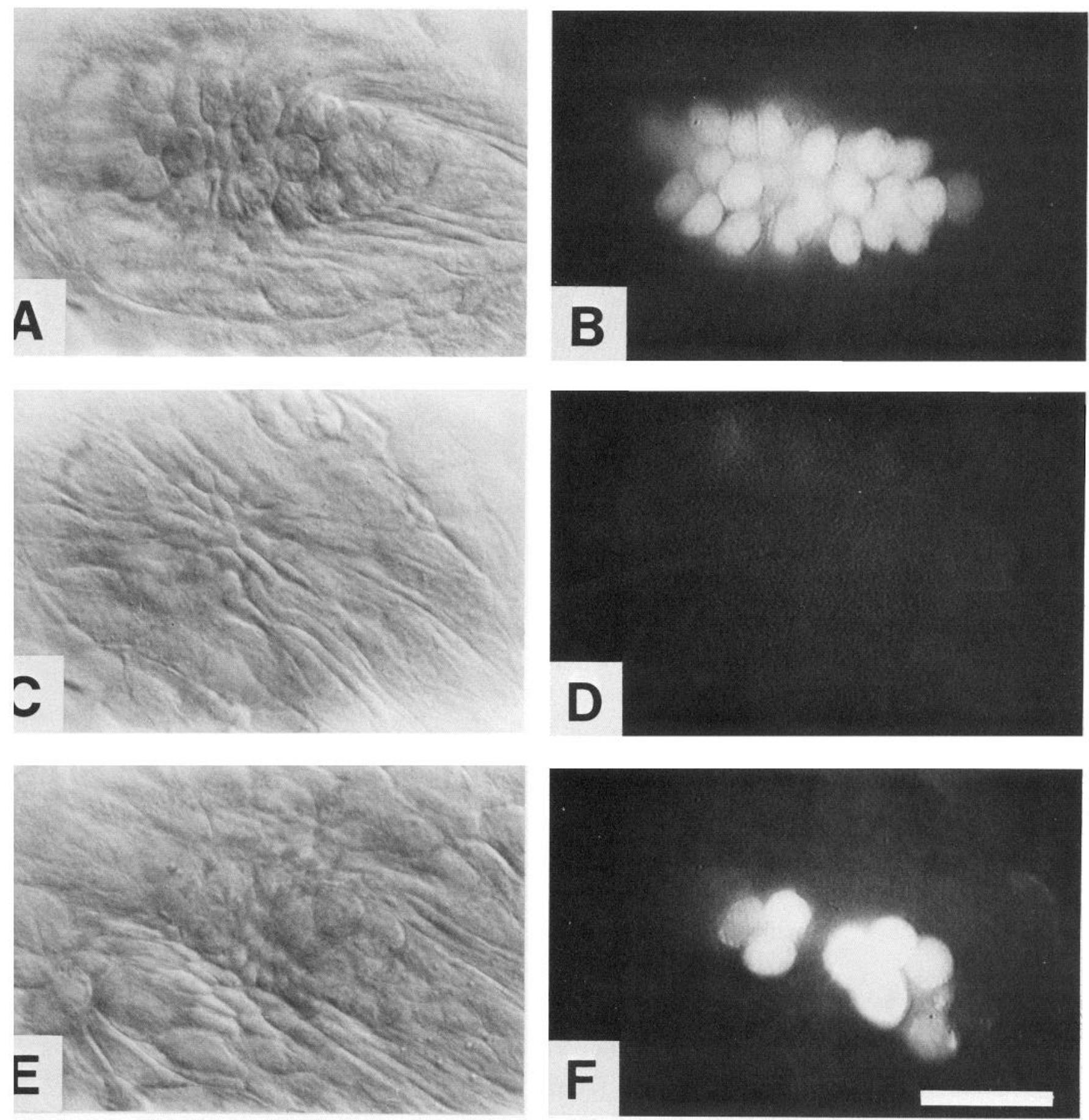

Figure 3. Hair cell regeneration following the phototoxic ablation of preexisting hair cells in a lateral line neuromast treated with DASPEI. The same neuromast observed by vital microscopy is shown in all 6 micrographs. DIC views focused at the normal level of the hair cell nuclei are shown in $A, C$, and $E$. Epifluorescent images from the output of a SIT camera displayed on a video monitor show the neuromast after 20 min immersions in $1 \mathrm{~mm}$ DASPEI in $B, D$, and $F$. $A$, Hair cells recognizable by the circular outlines of their centrally positioned nuclei; $B$, same hair cells distinguishable because of their selective uptake of the DASPEI label at the start of the phototoxic treatment. $C$ and $D$, Same neuromast $1 \mathrm{~d}$ later, after all of the preexisting hair cells had been killed and lost, leaving an epithelium that contained only supporting cells. $E$ and $F$, Neuromast $9 \mathrm{~d}$ later after new hair cells had been produced by regeneration. Scale bar, $50 \mu \mathrm{m}$.

the same within the margin of counting error, before hair cell ablation and $1 \mathrm{~d}$ later. After the treatment, internal supporting cells and mantle-type supporting cells were the only resident cells in these sensory epithelia.

The rate of hair cell regeneration was determined by observing individual treated neuromasts every 3 or $4 \mathrm{~d}$ by DIC microscopy and by fluorescence video microscopy following immersion in DASPEI during the recovery period after complete ablation of all preexistent hair cells. Data from 10 salamanders are shown in Figure 4 . The first regenerated hair cells usually appeared by 


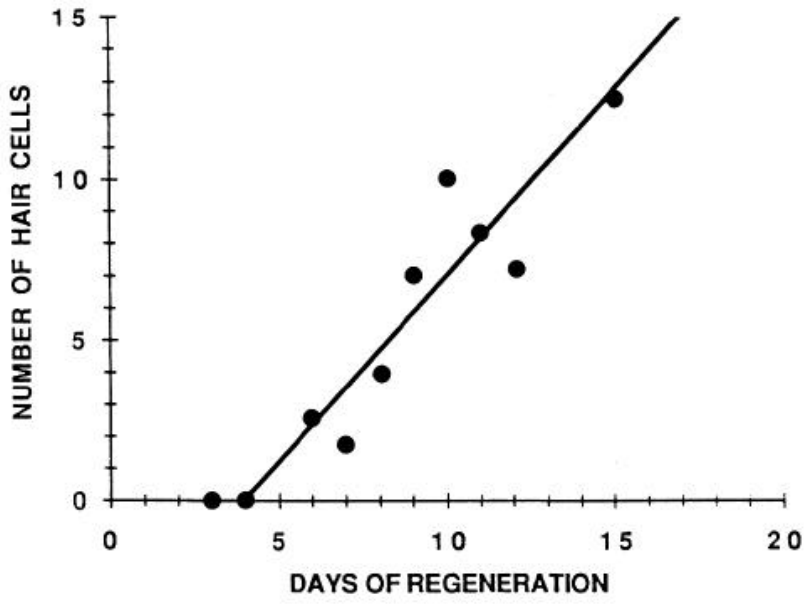

Figure 4. Mean rate of hair cell regeneration following phototoxic ablation of all preexisting hair cells. All the hair cells of a single neuromast from 10 different axolotls were killed by exposure to DASPEI and subsequent bleaching by epifluorescent illumination. The regenerated hair cells in each neuromast were counted at 3-4 d intervals. The cells were visualized by DIC microscopy and by fluorescent videomicroscopy after labeling in DASPEI. The first regenerated hair cells appeared within $6 \mathrm{~d}$ of phototoxic ablation. After that, the populations grew at a rate of approximately 1 hair cell every $1-2 \mathrm{~d}$.

day 6 . New hair cells were added roughly once a day, for at least $15 \mathrm{~d}$ after that. One neuromast regenerated 19 hair cells in the $15 \mathrm{~d}$ after treatment.

\section{Laser experiments}

In a second approach a laser microbeam was focused on individual hair cell nuclei, and a single pulse of the laser was used to kill each cell as shown in Figures 1 and 5. The hair cells killed in this way were extruded from the sensory pore at the surface of the neuromast within $15 \mathrm{~min}$ (Fig. 6). The epidermal cells above the sensory epithelium (Fig. 7) and the supporting cell nuclei beneath the hair cells (Fig. 8) showed no signs of damage in the cases that were used for further study. It is possible that some undetected damage occurred in those populations of cells, but if so, this was at much lower levels of occurrence than the immediate damage in the hair cell population.

The energy level of the laser pulse was varied to test for effectiveness in hair cell ablation. The size of the coagulation caused by the laser pulse increased as the energy level increased over a limited range. Lower energy levels did not produce a noticeable coagulation, and high levels resulted in the generation of a small gas bubble in the nucleus, presumably as a result of complete ionization of molecules that appeared to produce an ionized plasma at the point of focus. Laser pulse energies were controlled so as to avoid the production of large ionization bubbles or noticeable damage in the thin epidermal cells that cover the surfaces of the neuromasts. Seconds after a laser treatment that produced a noticeable coagulation or a small bubble in the nucleus, the nuclear envelope of the cell changed to a DIC-bright appearance. While the laser ablation was in progress, cells that had been treated were distinguishable from those that had not because of the greater contrast in phase between the nuclear contents and the nuclear envelope in the treated cells as visualized by DIC optics. Within 2-3 min the nuclei and the cell bodies of the treated cells began to move toward the sensory

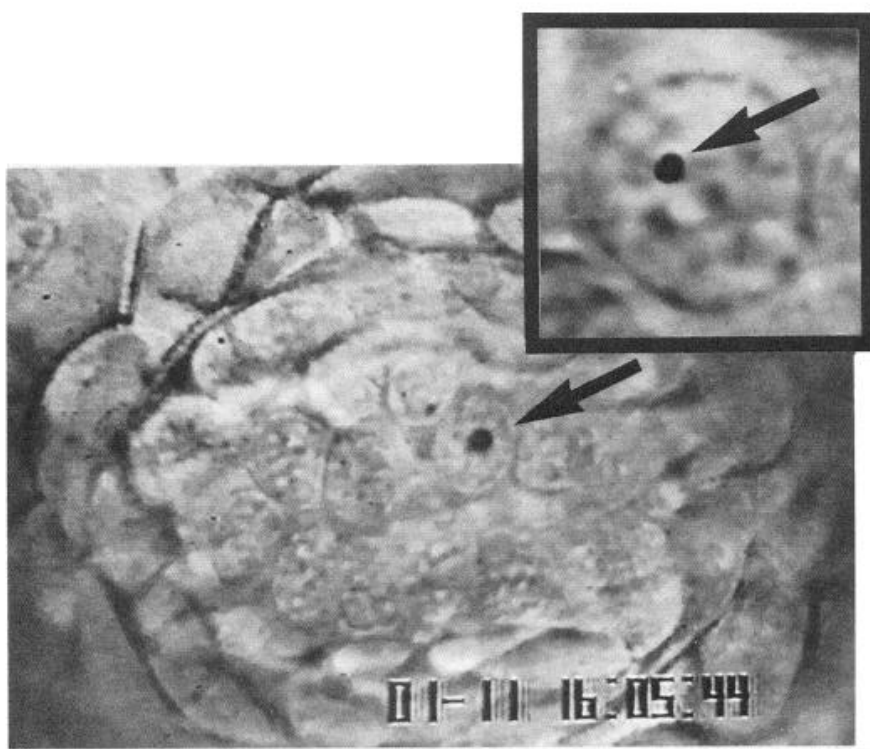

Figure 5. Laser microbeam pulse irradiation in hair cell nuclei. The video DIC microscope image captures the small circular coagulation that is the transient effect, lasting several seconds, produced by a 3-nsec pulse of the UV laser microbeam focused in the nucleus of one hair cell (arrow) in a lateral line neuromast. Inset, Relative size of the coagulation effect (arrow) in an enlarged view of another hair cell nucleus. At higher intensities of light, the laser pulses result in the rapid formation of a small gas bubble that then more slowly collapses inside the nucleus. It appears that bubble formation results from the generation of a plasma of ionized vapor produced when the combined electric field strength of the photons of light causes ionization at the site of focus.

pore, where they began to be extruded from the epithelium. Extrusion of all the treated sensory hair cells was complete within $15 \mathrm{~min}$ of the beginning of hair cell ablation.

A neuromast depleted of sensory hair cells is shown in Figure $8 B$. It consists of supporting cells that are in contact with the basal lamina below and are covered by a thin epidermal cell layer above. Initially, after laser ablation and extrusion of the hair cells, the treated neuromasts appear hollow, with a prominent opening at the site formerly occupied by the sensory pore and with an extracellular space located internally, at the site previously filled by the bodies of the hair cells. Then, in 1-2 hr, the remaining supporting cells gradually shift positions to form a flatter epithelium, filling in the space left by the extruded hair cells. Time-lapse records from that period reveal that the cellular rearrangements that result in the flattened epithelium occur through lamellipodia-mediated motility of individual cells in the neuromast. This type of motility is normally associated with cell migrations over distances (Trinkaus, 1984), but here the centers of the motile cells barely change position. One day after the laser ablation, these neuromasts closely resemble those produced by phototoxic ablation with DASPEI. The cells are flattened and those at the anterior and posterior ends of the neuromasts are elongated along their anteroposterior axes.

The rate of hair cell regeneration following laser-induced hair cell ablation was monitored by daily observation via DIC microscopy. Data from 6 treated salamanders are shown in Figure 9. In response to the selective cell surgery provided by the laser microbeam method, the regenerative replacement can occur rapidly. In one case the first regenerated hair cell had extended a kinocilium and a small bundle of short stereocilia just $3 \mathrm{~d}$ 

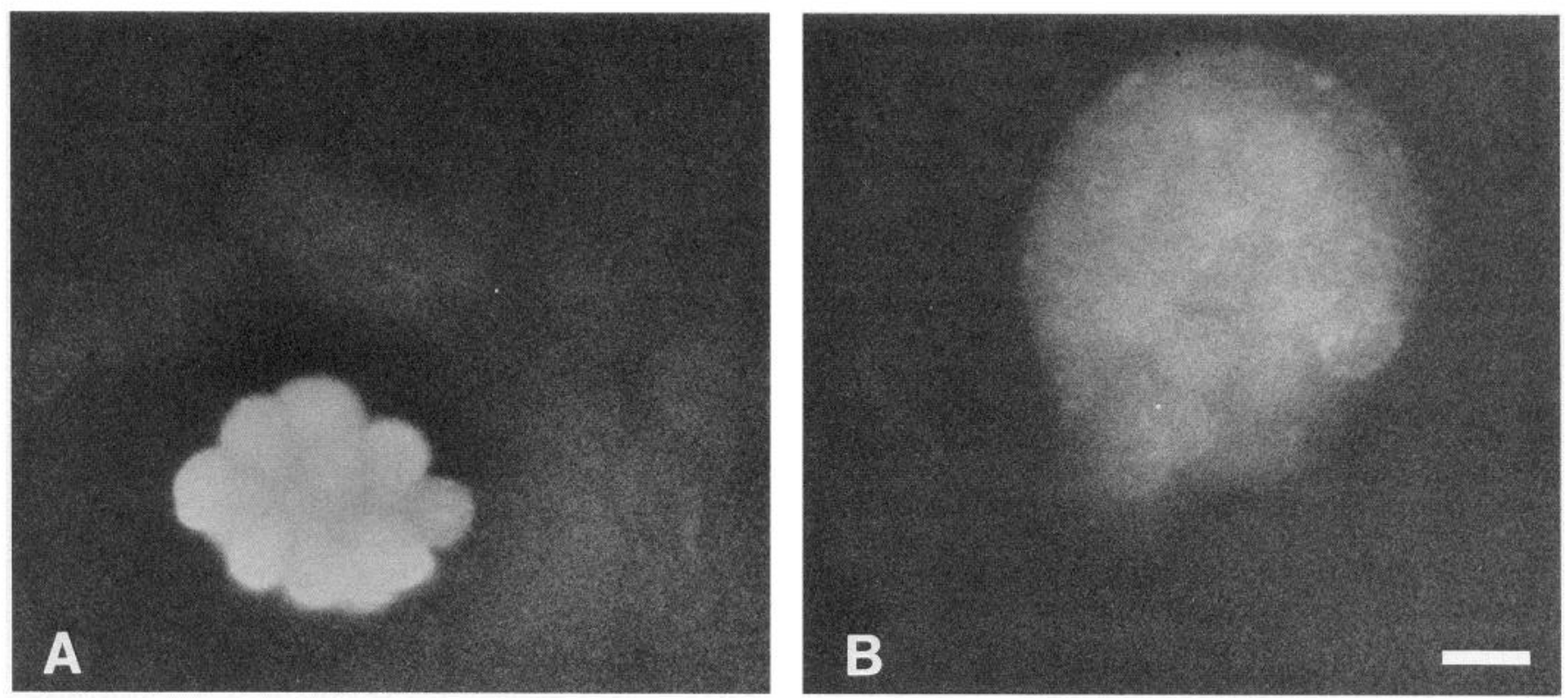

Figure 6. Extrusion of hair cells following laser ablation. The same lateral line neuromast after $60 \mathrm{sec}$ immersion of the animal in DASPEI viewed by epifluorescence before $(A)$ and $12 \mathrm{~min}$ after $(B)$ laser ablations of all of the hair cells in the epithelium. DASPEI was selectively taken up by the hair cells so that their positions in the epithelium before laser treatment could be determined in $A$. After the hair cells are killed by pulses of the laser microbeam, they lose attachments to the surrounding cells in the epithelium and move toward the sensory pore in the center of the neuromast's apical surface. The epidermal cells remain intact covering the entire surface of the neuromast except at its sensory pore, where hair cells and supporting cells reach the external surface. The sensory pore erupts soon after laser ablation of the hair cells and the remains of the hair cells are extruded through the sensory pore into the fluid outside the animal. In this experiment, the prior loading of the hair cells with DASPEI allowed the relocation of their remains outside and just above the skin surface after their extrusion from the epithelium. $A$ and $B$, Same field at slightly different planes of focus. The nuclei of hair cells are visible in the DASPEI-labeled mass in $B$. DASPEI labeling was no longer present inside the neuromast $12 \mathrm{~min}$ after laser ablation. Scale bar, $20 \mu \mathrm{m}$.

after the laser treatment. In almost all cases, the first stereocilia of regenerated hair cells appeared by $5 \mathrm{~d}$ after the laser ablation. By day 16 postablation, the laser-treated neuromasts in this group of 6 salamanders averaged approximately 7.5 hair cells

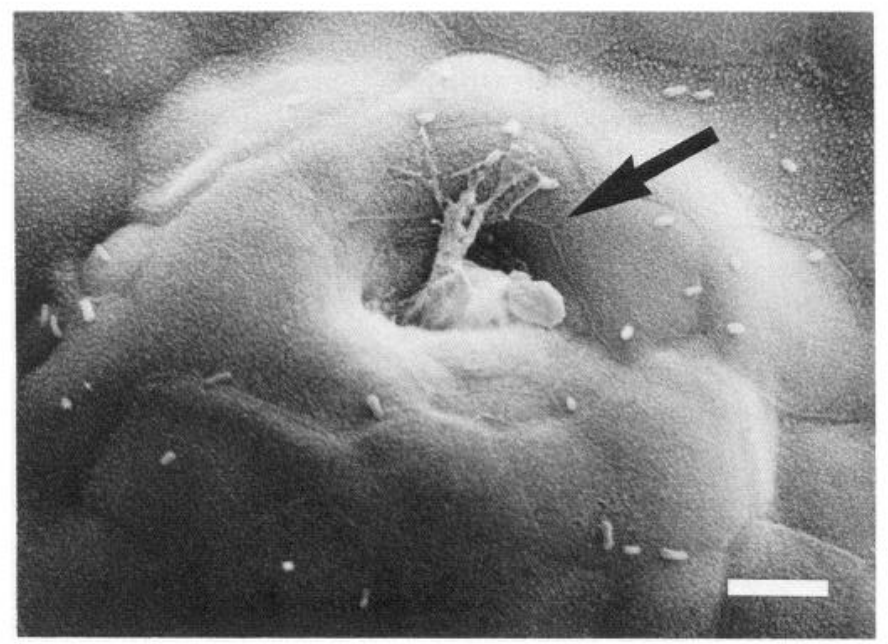

Figure 7. Scanning electron micrograph of the surface of a lateral line neuromast after laser ablation and extrusion of its hair cells. The arrow points to the former location of the sensory pore, where the apical surfaces of the hair cells and supporting cells previously communicated with the outside environment. The epithelium was fixed $100 \mathrm{~min}$ after lasing, well past the time of hair cell extrusion. Notice that the epidermal cells covering the surface of the neuromast are intact even though the laser pulses passed through those cells on their paths converging in the nuclei of the hair cells beneath. Compare to the intact neuromast in Figure 2. Scale bar, $10 \mu \mathrm{m}$. each. One neuromast had regenerated 14 hair cells $18 \mathrm{~d}$ after complete elimination of all preexisting hair cells.

The cellular events occurring after a complete laser ablation of the hair cell population in one neuromast in each of 3 salamanders were observed in 34-164 hr time-lapse records. In one case, the period of time-lapse recording began $6 \mathrm{hr}$ after the laser ablation of all the hair cells in the neuromast and continued beyond the time when 3 hair cells had been produced by regeneration $125 \mathrm{hr}$ later. That neuromast contained 15 hair cells, approximately 30 internal supporting cells, and approximately 15 mantle-type supporting cells before laser ablation. Following that, a total of 21 internal supporting cell mitoses were recorded (Fig. 10). Seven divisions occurred during the first $100 \mathrm{hr}$ of observation; the remaining 14 occurred during the subsequent $64 \mathrm{hr}$, when the first hair cell replacements appeared. In 4 control salamanders, neuromasts that were about the same size and age as the laser-treated neuromasts were observed for comparison. There the average interval between mitoses in internal supporting cell populations was $9 \mathrm{hr}$, with a SD of $4 \mathrm{hr}$.

The mantle-type supporting cell population of the laser-treated neuromast was also mitotically active. A total of 15 mantle cell mitoses were recorded; 11 occurred during the first $100 \mathrm{hr}$, but only 4 during the next $64 \mathrm{hr}$. It seems likely that most of the mitotic activity in the normally quiescent mantle cells was associated with budding processes that led to the formation of the 2 secondary sensory epithelia (see Discussion). At the time of the laser ablation, the neuromast was in the process of forming a secondary neuromast by budding from its posteroventral side. A second bud developed from the neuromast at its anteroventral side, beginning $87 \mathrm{hr}$ after the laser treatment. However, the laser treatment may have stimulated some mantle cell mitoses, 

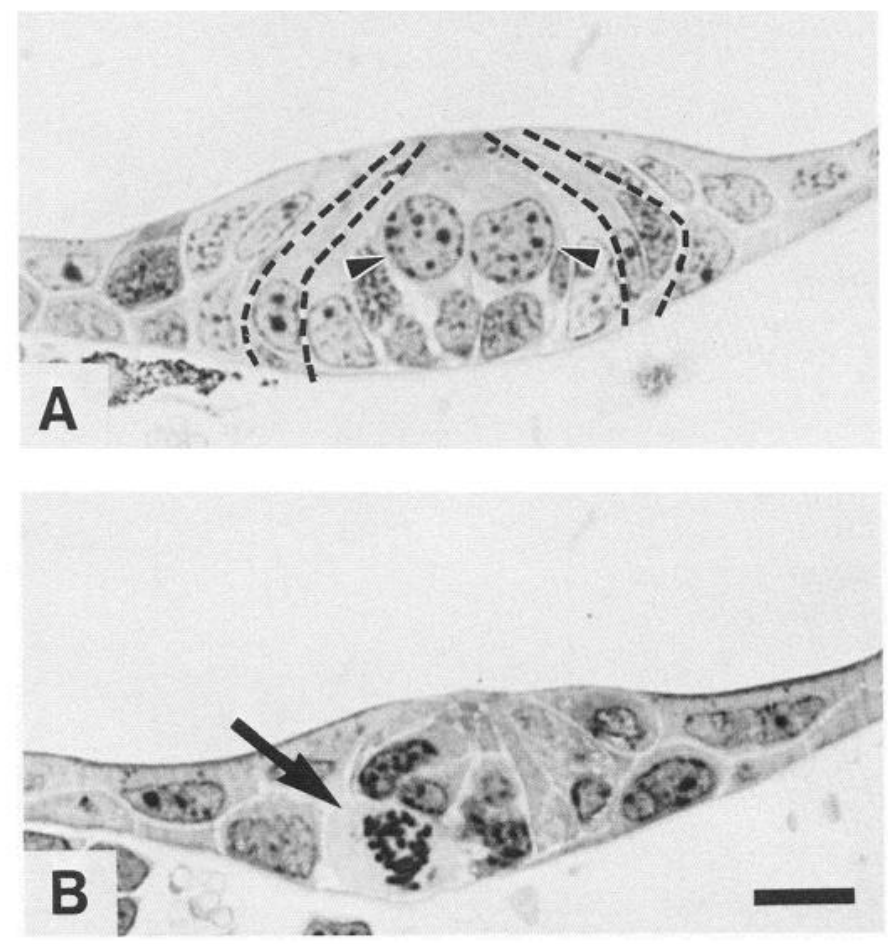

Figure 8. Sections of an intact and a treated neuromast after laser ablation of the hair cells. $A$, Two hair cells (between the arrowheads) identifiable by their centrally positioned, spherical nuclei in the middle of an intact neuromast. Dashed lines mark the approximate boundaries between the epidermis outside neuromast's mantle-type supporting cells and the inner boundaries between the mantle-type supporting cells and the internal supporting cells. $B$, Section through the middle of the adjacent neuromast fixed $12 \mathrm{hr}$ after laser ablation of all of its hair cells. The hair cells are no longer present in the neuromast. The transient extracellular space created after their extrusion has been filled in and the populations of overlying epidermal cells and underlying and surrounding supporting cells appear healthy, even though the laser pulses passed through both of those cell populations, as the light converged and diverged along the focused path of the microbeam. The arrow indicates a supporting cell that is in contact with the basal lamina and that is in an early phase of mitosis. Scale bar, $15 \mu \mathrm{m}$.

since 8 mantle cell divisions occurred at the dorsal side of the neuromast, opposite the buds.

Three spherical, centrally located hair cell nuclei first became identifiable $131 \mathrm{hr}$ after laser ablation of the original sensory cells. The sensory hair bundles of these cells became visible at $136 \mathrm{hr}$ (Fig. 11). Internal supporting cell mitoses were observed near the sites where the new hair cells arose, and no cells from outside the neuromast were observed taking up residence in the neuromast, at any time.

At the end of the time-lapse period, there were approximately 30 internal supporting cells in the neuromast, roughly the same number that were present at the start of the observations. Although 21 divisions of internal supporting cells occurred, the population did not grow appreciably, because at least 15 internal supporting cells were phagocytosed by macrophages during the time-lapse observation. Macrophages were recognizable because of their rapid motility and their phagocytic action.

The branch of the lateral line nerve that contacted the lasertreated neuromast appeared normal throughout the recording. Blood flow in the capillaries beneath the neuromast remained strong.

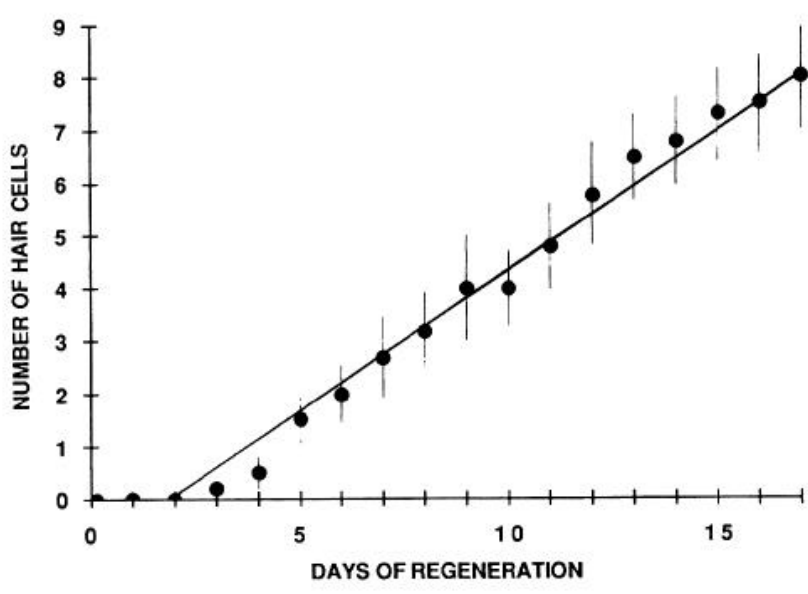

Figure 9. Regeneration after laser ablation of all preexisting hair cells. A single laser-treated neuromast in the tail of each of 6 salamanders was monitored daily by DIC microscopy. The mean number of hair cells present is shown by each point. Vertical lines indicate SEs. In one case, hair cells with recognizable sensory hair bundles appeared $3 \mathrm{~d}$ after ablation. In almost all cases, the first hair cells appeared by $5 \mathrm{~d}$ after ablation. The average number of hair cells in the monitored sample of epithelia grew at a nearly constant rate during the subsequent 2 weeks.

\section{Discussion}

These results demonstrate that hair cells can regenerate in experimentally lesioned lateral line sensory epithelia that contain no hair cells and only one resident cell type, supporting cells. As in the regeneration of hair cells in the ear, the replacement hair cells in the lateral line arise from progeny of new cell divisions. After complete ablation, new hair cells can arise in less than $72 \mathrm{hr}$, and 4-9 hair cells continue to be produced each week for at least 2 weeks. Supporting cells, which survive the DASPEI and the laser treatments, increase their mitotic activity soon after ablation of hair cells. Some of the progeny produced by the divisions of these cells differentiate into new hair cells.

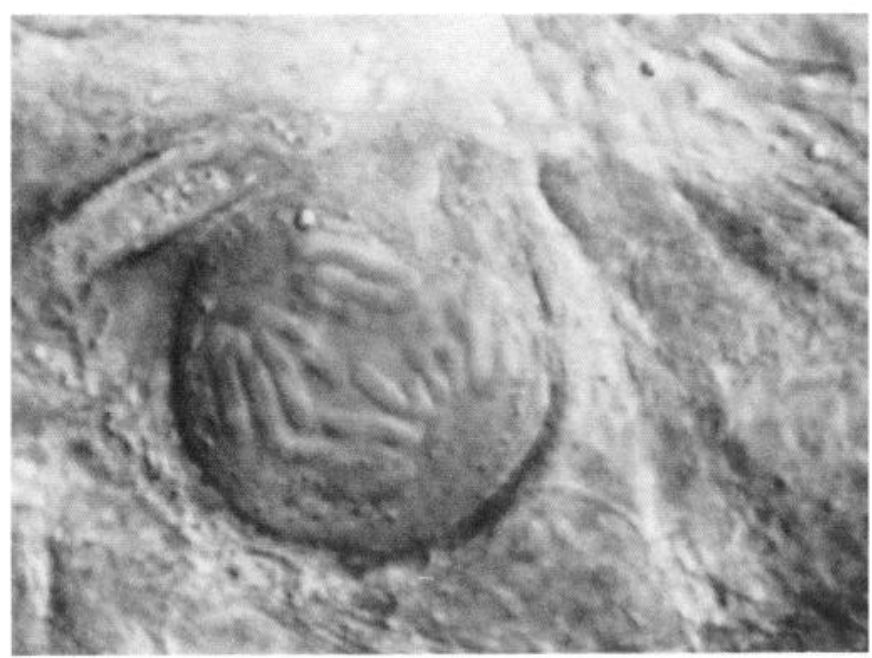

Figure 10. A DIC view of a supporting cell in anaphase of mitosis. Time-lapse video microscopy was used to chart the course of similar cell divisions that was evoked by the laser ablations and led to the regenerative production of replacement hair cells. As outlined in the text, it appears that the internal population of supporting cells is most responsive in this form of hair cell regeneration. 

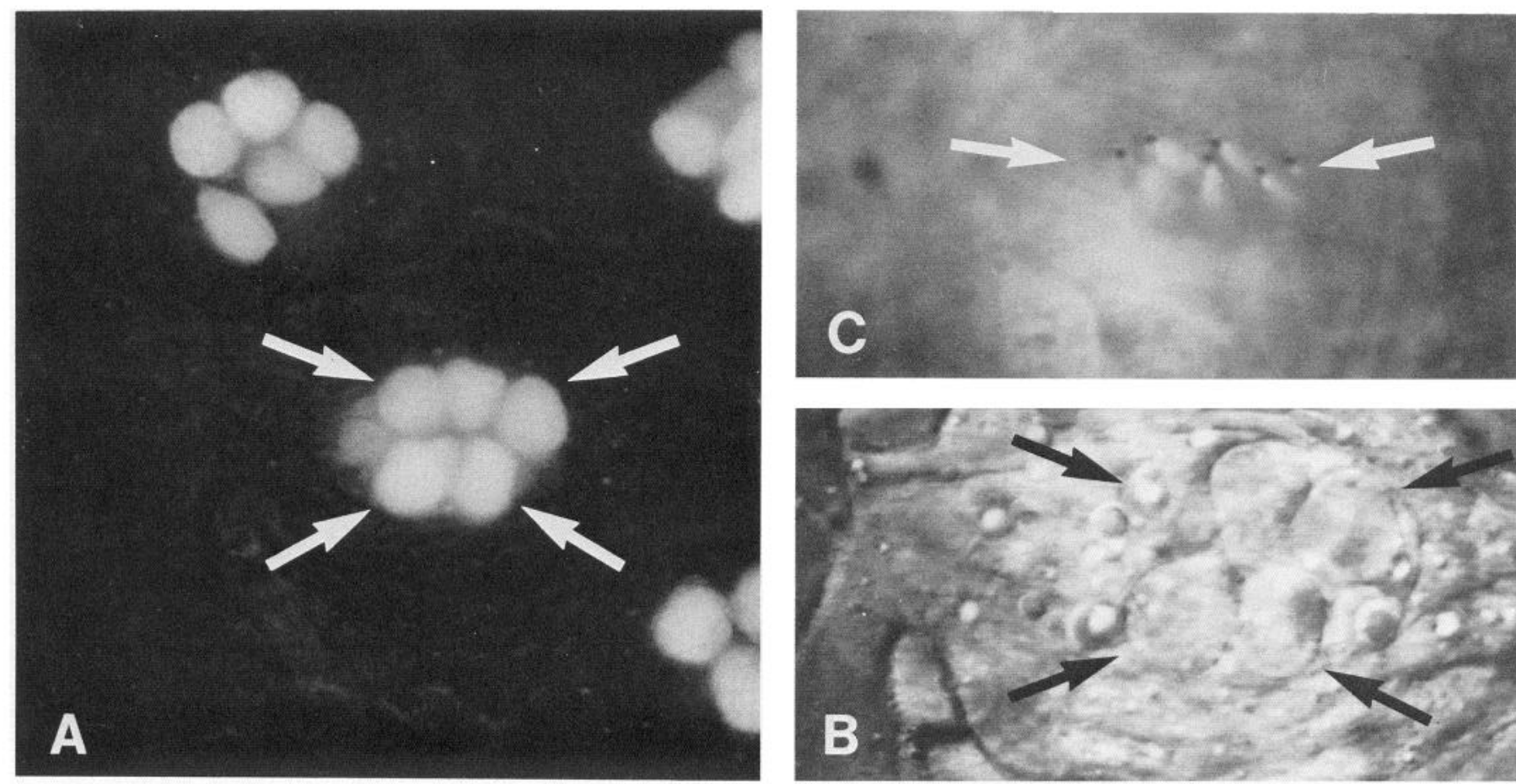

Figure 11. Hair cells produced after laser ablation and time-lapse observation. The preexisting hair cells in this neuromast were ablated by the laser microbeam, then cell divisions in the remaining supporting cells and the activities of macrophages were monitored through nearly continuous time-lapse microscopy over the course of $6 \mathrm{~d}$, as outlined in the text. Three hair cell nuclei first became recognizable $131 \mathrm{hr}$ after laser ablation; their sensory hair bundles were recognizable by $136 \mathrm{hr}$. The preparation was then removed from the time-lapse apparatus for transport between laboratories. At the end of that period, $10 \mathrm{~d}$ after the laser ablation, it was examined by vital microscopic methods that demonstrated a total of 6 regenerated hair cells. $A$, Epifluorescence shows the 6 regenerated hair cells (arrows) in the laser-treated neuromast after a 60 sec immersion in 1 mm DASPEI. $B$, The nuclei of the regenerated hair cells are visible in this DIC micrograph focused in the middle of the sensory epithelium. $C$, The sensory hair bundles of the 6 regenerated hair cells are visible in this DIC micrograph focused at the apical surface of the epithelium.

\section{Phototoxicity}

We used a high concentration of DASPEI in these experiments, but it is noteworthy that DASPEI has been used for vital staining of neuromuscular junctions at $10 \mu \mathrm{M}$, a 100 -fold dilution relative to the concentration we used (Magrassi et al., 1987). At least $75 \%$ of the hair cells exposed to $1 \mathrm{mM}$ DASPEI were killed by as little as $5 \mathrm{~min}$ of epifluorescent illumination.

DASPEI and similar so-called "mitochondrial" dyes are cationic. Under some conditions they appear to accumulate in respiring mitochondria because of the internally negative potential difference across the mitochondrial membrane (Johnson et al., 1980, 1981). DASPEI incubation of hair cells in the avian cochlea labels small organelles, which are presumed to be mitochondria (M. E. Warchol, unpublished observation). However, DASPEI labeling of the lateral line appears to be evenly distributed throughout the cytoplasm and the nucleus of the hair cells, but it is not present in adjacent supporting cells. Both the hair cells and the supporting cells of the lateral line reach the external surface, but differences in the ion channels and carriers that are exposed may account for their difference in labeling. Also, the transmembrane potentials of hair cells are greater than those of supporting cells in these neuromasts $(\mathrm{K}$. J. Balak, unpublished observations), and membrane potentials have been shown to affect the uptake of similar cationic dyes into whole cells (Sims et al., 1974; Waggoner, 1979).

\section{Laser cell ablation}

The use of a laser microbeam provides several significant advantages over other methods for selective lesioning in hair cell epithelia. Microbeam disruption is controllable in intensity and in location, so a lesion can be placed in a subcellular compartment of an individually selected cell without noticeable damage to overlying or surrounding cells (Berns, 1974; Berns et al., 1981). The selected cell and its neighbors can be continually visualized before, during, and after the lesion is produced. There is precise control over the timing of the lesion, and rapid cell death. In the lateral line, the method results in extrusion of the killed cells from the treated neuromasts.

\section{Progenitors of regenerated hair cells}

Following the elimination of the hair cells from a lateral neuromast, the supporting cells of that neuromast begin to divide with increased frequency, eventually giving rise to cells that differentiate as replacement hair cells. Supporting cells in undamaged sensory epithelia of the lateral line normally divide much less frequently than those in neuromasts where the hair cells have been ablated. Time-lapse observations have previously demonstrated that the populations of the internal supporting cells and the mantle-type supporting cells in lateral line neuromasts are characterized by significantly different rates of proliferation (Jones and Corwin, 1988). Under conditions of normal growth, mitoses occur in the internal populations of supporting cells approximately once every $9 \mathrm{hr}$, in neuromasts that each contain approximately 30 internal supporting cells, 15 mantle-type supporting cells, and 15 hair cells. In contrast, mantle-type supporting cells are mitotically quiescent under those conditions, with less than 1 division occuring in $5 \mathrm{~d}$, on average. When the lateral line is growing by addition of secondary neuromasts or through regeneration that has been triggered by am- 
putation of the tip of the tail, new neuromasts are generated by budding at the edges of preexisting neuromasts (Stone, 1937; Corwin, 1986; Corwin et al., 1989). During budding, the ratc of mitosis in the internal supporting cells does not change, but the rate of cell division in the population of mantle-type supporting cells increases rapidly (Jones and Corwin, 1988). After laser ablation, the first appearance of regenerated hair cells was preceded by a high rate of cell division in the internal supporting cells, but this was accompanied by a low rate of division in the mantle-type supporting cells. For that reason, we suspect that the cell divisions that gave rise to the regenerated hair cells occurred in internal supporting cells, but divisions of mantletype supporting cells could have given rise to the hair cells. However, it seems most likely that the mitotic activity of mantle-type supporting cells was related to budding of 2 new neuromasts that occurred at the edge of that neuromast, rather than to the replacement of the central hair cells that had been killed by the laser treatment.

Supporting cells have been proposed as progenitors of replacement hair cells produced during regeneration in the avian cochlea (Corwin and Cotanche, 1988), and it has recently been proposed that hyaline and cuboidal cells that normally lie outside the inferior edge of that cochlear sensory epithelium can give rise to progeny that may migrate into damaged regions of the epithelium and differentiate into hair cells and supporting cells (Girod et al., 1989). It may be that 2 or 3 types of cells can act as progenitors to regenerated hair cells as proposed (Girod et al., 1989), but that has not been established. It is clear that more evidence is needed to identify which of the several proposed progenitors in the avian epithelium actually gives rise to new hair cells.

\section{Hair cell extrusion}

Regenerative production of hair cells can be evoked by compromising the metabolism of a preparation (Corwin, 1986), by acoustic overstimulation (Cotanche, 1987; Corwin and Cotanche, 1988; Ryals and Rubel, 1988), by aminoglycoside poisoning (Cruz et al., 1987; Lippe et al., 1989), by phototoxic poisoning, and by laser microbeam irradiation of existing hair cells in an epithelium. All of those manipulations, with the exception of aminoglycoside poisoning, which has not been subjected to careful posttreatment observation, are known to result in extrusion of the dead or dying hair cells from the sensory epithelium. It may be that the extrusion of hair cells from the epithelium stimulates a reactive proliferation of remaining cells and the differentiation of new cells as replacements. In the chicken cochlear epithelium regeneration occurs where hair cells have been lost, but at sites where hair cells have been significantly damaged and remain in the epithelium, regenerative replacement does not appear to occur (Cotanche, 1987; Corwin and Cotanche, 1988). The laser ablations of DASPEI-filled hair cells (Fig. 6) suggest that hair cells do not have to break up for regeneration to be triggered, if the cells are extruded.

Changes in adhesive contacts and the degree of phosphorylation of tyrosine residues in proteins that link elements of the cytoskeleton to the adhesive junctions of cells appear to have a role in triggering the proliferation of tumor cells after transformation by viral oncogenes (Burridge et al., 1988). Mechanisms that control cell proliferation are likely to be widely shared, so the breaking of adhesive links and the remodeling of cytoskeletons caused by the extrusion of preexisting hair cells might be expected to have a role in the release of supporting cells from inhibition of proliferation mediated through cell contact. Al- ternatively, the destruction of the hair cells might cause the release of degradation products, other compounds, or electrical currents that act directly or indircctly to induce proliferative activity. Macrophages release mitogens and are active in neuromasts early in regeneration (Jones and Corwin, 1988).

In mammalian ears, sites of hair cell loss are marked by socalled "scars," where adjacent supporting cell surfaces expand to fill the positions on the cochlear surface that would normally be occupied by hair cells (Bredberg, 1968). Also, outer hair cells that have been killed do not leave the epithelium until the surrounding supporting cells form new junctions that provide continuity in the reticular lamina (Forge, 1985).

If the specific triggers of supporting cell proliferation could be identified in hair cell epithelia that have the capacity for regeneration, such as the sensory epithelia of the lateral line or the avian cochlea, those triggers might be capable of stimulating self-repair in mammalian epithelia. The large human population that is affected by loss of hair cells and the resulting loss of auditory sensitivity, which are currently considered irreversible, provides a compelling reason to seek those triggers.

\section{References}

Balak KJ, Corwin JT (1988) Hair cells originate from supporting cell progeny during regeneration in the lateral line system. Assoc Res Otolaryngol Abstr 11:107.

Bereiter-Hahn J (1976) Dimethylaminostyryl-methyl-pyridinium-iodine (DASPEI) as a fluorescent probe of mitochondria in situ. Biochim Biophys Acta 423:1-14.

Berns MW (1974) Biological microirradiation. Englewood Cliffs, NJ: Prentice-Hall.

Berns MW, Aist J, Edwards J, Strahs K, Girton J, McNeill P, Rattner JB, Kitzes M, Hammer-Wilson M, Liaw L-H, Siemens A, Koonce M, Peterson S, Brenner S, Burt J, Walter R, Bryant PJ, vanDyk D, Coulombe J, Cahill T, Berns GS (1981) Laser microsurgery in cell and developmental biology. Science 213:505-513.

Bredberg G (1968) Cellular pattern and nerve supply of the human organ of Corti. Acta Otolaryngol [Suppl] (Stockh) 236:1-136.

Burridge K, Fath K, Kelly T, Nuckolls G, Turner C (1988) Focal adhesions: transmembrane junctions between the extracellular matrix and the cytoskeleton. Annu Rev Cell Biol 4:487-525.

Corwin JT (1977) Ongoing hair cell production, maturation, and degeneration in the shark ear. Soc Neurosci Abstr 3:4.

Corwin JT (1981) Postembryonic production and aging of inner ear hair cells in sharks. J Comp Neurol 201:541-553.

Corwin JT (1984) Dynamic changes in cell populations and neuronal connections accompany continuing postembryonic growth in the ear. Assoc Res Otolaryngol Abstr 7:56-57.

Corwin JT (1985) Perpetual production of hair cells and maturational changes in hair cell ultrastructurc accompany postembryonic growth in an amphibian ear. Proc Natl Acad Sci USA 82:3911-3915.

Corwin JT (1986) Regeneration and self-repair in hair cell epithelia: experimental evaluation of capacities and limitations. In: Biology of change in otolaryngology (Ruben RJ, Van deWater TR, Rubel EW, eds), pp 291-304. New York: Elsevier.

Corwin JT, Cotanche DA (1988) Regeneration of sensory hair cells after acoustic trauma. Science 240:1772-1774.

Corwin JT, Balak KJ, Borden PC (1989) Cellular events underlying the regenerative replacement of lateral line sensory epithelia in amphibians. In: The mechanosensory lateral line: neurobiology and evolution (Coombs S, Görner P, Munz H, eds), pp 161-183. New York: Springer.

Cotanche DA (1987) Regeneration of hair cell stereociliary bundles in the chick cochlea following severe acoustic trauma. Hearing Res 30:181-196.

Cotanche DA, Saunders JC, Tilney LG (1987) Hair cell damage produced by acoustic trauma in the chick cochlea. Hearing Res 25:267286.

Cruz RM, Lambert PR, Rubel EW (1987) Light microscopic evidence of hair cell regeneration after gentamicin toxicity in chick cochlea. Arch Otolaryngol Head Neck Surg 113:1058-1062.

Forge A (1985) Outer hair cell loss and supporting cell expansion following chronic gentamicin treatment. Hear Res 19:171-182. 
Girod DA, Duckert LG, Rubel EW (1989) Possible precursors of regenerated hair cells in the avian cochlea following acoustic trauma. Hear Res 42:175-194.

Johnson LV, Walsh ML, Chen LB (1980) Localizations of mitochondria in living cells with rhodamine 123. Proc Natl Acad Sci USA 77: 990-994.

Johnson LV, Walsh ML, Bockus BJ, Chen LB (1981) Monitoring of relative mitochondrial membrane potential in living cells by fluorescence microscopy. J Cell Biol 88:526-535.

Jones JE, Corwin JT (1988) Cellular origin of the regenerative placode during lateral line regeneration in the axolotl. Soc Neurosci Abstr 14: 1199.

Jørgensen JM (1981) On a possible hair cell turn-over in the inner ear of the caecilian Ichthyophis glutinosus (Amphibia:Gymnophiona). Acta Zool 62:171-186.

Jørgensen JM (1989) Evolution of octavolateralis sensory cells. In: The mechanosensory lateral line: neurobiology and evolution (Coombs S, Görner P, Munz H, eds), pp 115-145. New York: Springer.

Jørgensen JM, Mathiesen C (1988) The avian inner ear: continuous production of hair cells in vestibular sensory organs, but not the auditory papilla. Naturwissenschaften 75:319-320.

Katayama A, Corwin JT (1989) Cell production in the chicken cochlea. J Comp Neurol 281:129-135.

Lippe WR, Ryals BM, Westbrook EW (1989) Regeneration of hair cells in the chick basilar papilla following gentamicin toxicity. Assoc Res Otolaryngol Abstr 15:82-83.

Magrassi L, Purves D, Lichtman JW (1987) Fluorescent probes that stain living nerve terminals. J Neurosci 7:1207-1214.

Nielson DW, Slepecky N (1986) Stereocilia. In: Neurobiology of hearing: the cochlea (Altschuler RA, Hoffman DW, Bobbin RP, eds), pp 23-46. New York: Raven.
Ruben RJ (1967) Development of the inner ear of the mouse: a radioautographic study of terminal mitoses. Acta Otolaryngol [Suppl] (Stockh) 220:1-44.

Ryals BM, Rubel EW (1988) Hair cell regeneration after acoustic trauma in adult Coturnix quail. Science 240:774-776.

Rybak LP (1986) Ototoxic mechanisms. In: Neurobiology of hearing: the cochlea (Altschuler RA, Hoffman DW, Bobbin RP, eds), pp 441454. New York: Raven.

Saunders JC, Tilncy LG (1982) Specics differenecs in susceptibility to noise exposure. In: New perspectives on noise-induced hearing loss (Hamernik RP, Henderson D, Salvi R, eds), pp 229-248. New York: Raven.

Sims PJ, Waggoner AS, Wang C-H, Hoffman JF (1974) Studies on the mechanism by which cyanine dyes measure membrane potential in red blood cells and phosphatidylcholine vesicles. Biochemistry 13: 3315-3330.

Stone LS (1937) Further experimental studies of the development of lateral-line sense organs in the amphibians observed in living preparations. J Comp Neurol 68:83-115.

Tilney LG, Tilney MS (1986) Functional organization of the cytoskeleton. Hear Res 22:55-77.

Trinkaus JP (1984) Cells into organs. Englewood Cliffs, NJ: PrenticeHall.

Tucci DL, Rubel EW (1989) Regenerated hair cells in the avian inner ear following aminoglycoside ototoxicity are functional. Assoc Res Otolaryngol Abstr 12:83-84

Waggoner AS (1979) Dye indicators of membrane potential. Annu Rev Biophys Bioengin 8:47-68.

Yoo TJ (1986) Autoimmune disorders of the cochlea. In: Neurobiology of hearing: the cochlea (Altschuler R, Hoffman DW, Bobbin RP, eds), pp 425-440. New York: Raven. 